\title{
Optimal Capital Structure of the Enter- prise
}

\author{
Erika Spuchl'áková ${ }^{1}$ Juraj Cúg $^{2}$ \\ ${ }^{1,2}$ Ing. Erika Spuchláková, PhD., Ing. Juraj Cúg, PhD., Slovak Republic, University of \\ Žilina, the Faculty of Operation and Economics of Transport and Communications, \\ Department of Economics
}

\begin{abstract}
The aim of the paper is a holistic review of the issues associated with optimal capital structure, analysis of the impact of factors determining capital structure and empirical verification of validity of theories related to optimal capital structure in conditions specific for the Slovak Republic.
\end{abstract}

Key words: capital structure, size of the business, tangibility, profitability.

\section{Introduction}

While studying domestic and foreign literature pertaining to the issue of optimal capital structure, one could say that Slovak literature deals with models designed and verified abroad. However, these models have not yet been entirely applied and tested on businesses operating within the Slovak Republic.

We tried to carry out empirical research related to capital structure issues of Slovak businesses in the Slovak Republic by applying models designed in developed economies, e.g. Titman and Wessels (1988), Rajan a Zingales (1995), Graham a Harvey (2001). We examined their reporting ability and statistical significance and based on observed results the applicability of models was either recommended, modified or entirely rejected.

\section{Description and comparison of the analysed sample}

We gathered necessary data from forty companies operating in construction business for the years 2009 to 2011. For our own analysis of compliance with the conclusions of the theory of optimal capital structure, it was first necessary to identify and quantify the variable which could serve as basis for the construction of models as well as for the examination of selected hypotheses. This variable is clearly an indicator of total indebtedness. ${ }^{1}$

We have observed development of this variable both for the industry as such as well as for our sample. Table 1 shows the evolution of total indebtedness according to the industry and sample.

Table 1 Total indebtedness

\begin{tabular}{|l|l|l|l|}
\hline Year & $\mathbf{2 0 0 9}$ & $\mathbf{2 0 1 0}$ & $\mathbf{2 0 1 1}$ \\
\hline Total indebtedness of the sample & 0,71 & 0,74 & 0,77 \\
\hline Total indebtedness of the industry & 0,76 & 0,79 & 0,76 \\
\hline
\end{tabular}

As we can see, during the analysed period the total indebtedness of our sample rose from 0.71 to 0.77 . Conversely in the industry, we can see that after an initial increase from 0.76 to 0.79 in the year 2010 , in the year 2011, the total indebtedness fell to its original value of 0.76 .

\footnotetext{
1 Total indebtedness shall be determined as ratio of difference between total assets and equity and total assets of given business.
} 
We can also conclude that the values representing industry and our sample do not differ significantly.

In addition to the total indebtedness, it is necessary to analyse given debt's structure, i.e. to analyse the respective amount of short-term and long-term liabilities. For this reason we focused on long-term indebtedness, which is quantified as the ratio of long-term liabilities to total assets. Its development for the industry and our sample is stated in Table 2.

Table 2 Long-term indebtedness

\begin{tabular}{|l|l|l|l|}
\hline Year & $\mathbf{2 0 0 9}$ & $\mathbf{2 0 1 0}$ & $\mathbf{2 0 1 1}$ \\
\hline $\begin{array}{l}\text { Long-term indebtedness } \\
\text { of the sample }\end{array}$ & 0,05 & 0,06 & 0,06 \\
\hline $\begin{array}{l}\text { Long-term indebtedness } \\
\text { of the industry }\end{array}$ & 0,10 & 0,09 & 0,10 \\
\hline
\end{tabular}

Long-term indebtedness for the entire analysed period, both for industry and analysed sample did not exceed $10 \%$, which means that it is significantly lower than total indebtedness. The fact that the importance of the long-term indebtedness is marginal in capital structure of Slovak businesses may seem quite surprising at first sight. However, taking into account the amount and proportion of equity to total assets, it is clear that most businesses do not hold life of assets and maturity of financial resources used for their purchase in time line. Reasons for this cannot be found on side of businesses, but in their surroundings, i.e. in commercial banks and capital markets. It is because in order to minimize risk associated with long-term loans, Slovak banking institutions prefer short-term loans with short maturity periods, after repayment of which a new loan may be drawn. In other words, Slovak banks prefer revolving financing. The state of development of capital market (this type of market is rather undeveloped in the Slovak Republic) has also considerable impact on this fact. Businesses have limited opportunities for obtaining long-term financial re- sources in the form of bonds issued on the financial market.

\section{Capital Structure Determinants}

While searching for determinants of businesses` capital structure we have used conclusions obtained during study of foreign literature. Based on confrontation of these theoretical approaches and empirical data obtained by analysis of Slovak businesses capital structure and based on results of models designed abroad (e.g. Bradley, Jarrell, -1984; Kim Sorensen, 1986; Friend, I., Lang, L.-1988; Titman, S., Wessels, R.-1988; Chaplinsky, S., Niehaus, G.-1993; Frank, M. Z., Goyal, V. K.-2004; Kester, C. W.-1986; Rajan, G., Zingales, L.-1995; Wald, J.-1999; Bevan, A., Danbolt, J.-2000; Gaud, P.-2003; Wiwattanakantang, Y.-1999; Booth, L.2001; Huang, S.-2002) we have chosen following factors determining capital structure:

1. size of a business,

2. tangibility,

3. profitability,

4. non-debt tax shields,

5. risk,

6. growth (investment) opportunities,

7. results from previous years (i.e. delay in timing),

8. dummy variables.

In this paper, we will focus on the first three factors, i.e. the size of a business, tangibility and liquidity of assets and profitability.

\subsection{The size of the business}

We presumed that there is an inverse relationship between the size of a business and the probability of bankruptcy. Larger businesses achieve higher and more stable cash flows. These flows are also secured by a number of business activities, i.e. these are diversified. Therefore, the probability of bankruptcy of larger busi- 
nesses is lower than one of the smaller businesses. This fact is resulting from the trade-off theory which presumes that the size of the business and its debt are positively correlated.

A positive relationship between the size of a business and its debt is suggested also the Agency Theory. This theory stipulates that agency costs of small and large businesses are not the same due to the relatively higher costs of monitoring for small businesses. Probably due to lower informational asymmetry, larger companies have easier access to bond market, and can borrow at a lower cost.

On the other hand, relatively lower information asymmetry has exactly the opposite interpretation as regards the Pecking Order Theory. According to this theory, businesses with lower information asymmetry (e.g. large companies) prefer equity more than smaller businesses. In order to express the size of the business most published studies use the natural logarithm of sales. ${ }^{2}$.

\subsection{Tangibility}

Term "tangibility" could be easily translated as the collateral value of assets. According to the Trade-off Theory, businesses can use their tangible assets as collateral for repayment of debt, which allows gaining secured debt that is usually cheaper than the unsecured one. Tradeoff Theory together with Agency Costs Theory stipulates that the fact that ownership of tangible assets by businesses is positively tied up with its debt capacity.

On the other hand, Agency Costs Theory points out the cost of existing debt negotiation together with the fact that business may reorient on riskier investments by issuance of debt and to transfer wealth from creditors to stakeholders. If the business's tangible assets

\footnotetext{
${ }^{2}$ To reflect the size of the business, however, we can use the natural logarithm of total assets, tangible assets, etc.
}

are sufficiently "large", these could be used as collateral to reduce the creditor's risk. In general, high proportion of tangible assets is usually associated with higher indebtedness.

For businesses with a higher proportion of tangible asset, lower information asymmetry brings exactly the opposite conclusions when Pecking Order Theory is applied. As we already mentioned when discussing the variable "size of a business", fewer "troubles" with informational asymmetry lead to preference for equity. In other words, a negative relationship between tangible assets and indebtedness may be expected. As a variable, a ratio of tangible assets and total assets was used.

\subsection{Profitability}

Various theories do not offer a single prediction for profitability. While the Trade-off Theory, Signaling Theory and Agency Cost Theory expect a positive relationship between profitability and indebtedness, Packing Order Theory expects negative relationship. The argumentation is as follows:

The Trade-off Theory model assumes that the profitable businesses should lend more due to the fact these have a greater need for reduction of corporate taxes which is enabled by debt through tax shield. Agency Costs Theory, using different reasoning, considers the debt as a mean of discipline to ensure that managers procure for paying out of profits instead of building their own power. In businesses with free cash flow or high profitability, high debt may help keep manager's caution under control. In both cases then, a higher profitability should lead to higher indebtedness. Signalling Theory suggests that profitability and indebtedness are positively related. In case of informational asymmetry, the increase in debt gives the market signal on the 
value of the business, i.e. its expected profitability.

Packing Order Theory, on the other hand, argues that businesses prefer financing of new investments from profits retained during previous years, and that increase in own capital is used only if other forms of obtaining capital are not available. The ability to create internal capital resources depends on the profitability of business. Hence, according to this theory, it could be argued that there is a negative relation between debt and profitability.

As a criterion for measuring profitability, we have selected the respective share of operating profit EBIT on businesses' total assets as a criterion for measuring profitability, due to the fact that EAT and EBT levels of profit do not seem to be an adequate measure.

\section{Testing Hypothesis}

Based on data on forty Slovak businesses operating in construction business we have designed three models. Model I. has been designed on the basis of econometric analysis. Using this model, we have tried to describe indebtedness of Slovak businesses. Model II was designed as a standard linear regression model of dependence of total indebtedness of construction businesses on variables as are profits, tangibility, profitability and nondebt tax shield. Model III was designed based on the previous values, i.e. based on the delay in timing.

In the following part of this paper we would like to refer to testing of hypotheses related to given set of variables. In order to test the hypotheses, we have used our own empirical researches, analysis and respective mathematical and statistical instruments.

Prior to testing, it was necessary to determine critical values of Student and Fisher distribution. It also seemed neces- sary to follow relevant degrees of freedom, because these are different for almost any type of models. Their values are in the table 3 .

Table 3 Critical values of Student and Fisher distribution

\begin{tabular}{|c|c|c|c|c|c|c|c|c|c|c|}
\hline \multirow{2}{*}{$\begin{array}{l}\text { degree of } \\
\text { freedom }\end{array}$} & \multicolumn{5}{|c|}{$\mathrm{t}$ - test } & \multicolumn{5}{|c|}{$\mathrm{F}$ - test } \\
\hline & 35 & 34 & 33 & 114 & 115 & $(4 ; 35)$ & $(5 ; 34)$ & $(6 ; 33)$ & $(5 ; 114)$ & $(4 ; 115)$ \\
\hline$a=0,1$ & 1,69 & 1,6009 & 1,6923 & 1,6583 & 1,6582 & 2,1128 & 2,0244 & 1,9607 & 1,8985 & 1,9944 \\
\hline$\alpha=0,05$ & 2,0301 & 2,0322 & 2,0345 & 1,9809 & 1,9808 & 2,6415 & 2,4936 & 2,3894 & 2,2939 & 2,4506 \\
\hline$\alpha=0,01$ & 2,7238 & 2,7283 & 2,7332 & 2,6196 & 2,6192 & 3,0082 & 3,6106 & \begin{tabular}{|l|l|} 
& 3,4059 \\
\end{tabular} & 3,182 & 3,4867 \\
\hline
\end{tabular}

Source: Own calculations

\section{Hypothesis 1: The size of a business af-} fects its capital structure.

Based on data in Table 4 we have tested given hypothesis for all types of models and respective years. The size of a business was expressed as natural logarithm of sales. As we can see, the relationship between sales and indebtedness is positive for all models and years (positive mark by estimator). Based on this, we could state that by increasing volume of sales the volume of indebtedness also rises. However, statistical significance of this factor is low. It is due to the fact, that neither level of significance showed the absolute value of t-calculated higher or equal than critical values of respective degrees of freedom of Student distribution.

We have rejected hypothesis 1 , that the size of business expressed by natural logarithm of sales is statistically significant.

Table 4 Testing Table

\begin{tabular}{|c|c|c|c|c|c|c|c|c|c|c|}
\hline \multirow{2}{*}{\multicolumn{2}{|c|}{ In sales }} & \multicolumn{4}{|c|}{ Model I } & \multicolumn{4}{|c|}{ Model II } & \multirow{2}{*}{\begin{tabular}{|c|} 
Model III \\
$09-11$ \\
\end{tabular}} \\
\hline & & 2009 & 2010 & 2011 & 09-11 & 2009 & 2010 & 2011 & 09-11 & \\
\hline \multicolumn{2}{|c|}{ estimator } & + & 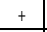 & $T$ & + & + & + & + & + & + \\
\hline \multicolumn{2}{|c|}{ t-calculated } & 0,01330 & 0,4090 & \begin{tabular}{|l|}
0,9998 \\
\end{tabular} & 0,1407 & 0,9676 & 0,7954 & 0,0373 & 0,98967 & 0,71 \\
\hline \multirow{3}{*}{$\begin{array}{c}\text { level of } \\
\text { significance }\end{array}$} & $\alpha=0,1$ & 1,6895 & 1,6895 & 1,6895 & 1,6582 & 1,6909 & 1,6909 & 1,6909 & 1,6583 & 1,69 \\
\hline & $\alpha=0,05$ & 2,0301 & 2,0301 & 2,0301 & 1,9808 & 2,0322 & 2,0322 & 2,0322 & 1,9809 & 2,03 \\
\hline & $\alpha=0,01$ & 2,7238 & 2,7238 & 2,7238 & 2,6192 & 2,7283 & 2,7283 & 2,7283 & 2,6196 & 2,73 \\
\hline
\end{tabular}

Source: Own calculations

If the size of a business is determined by natural logarithm of assets, the obtained results will appear slightly different if compared to previous model. The 
relationship between total indebtedness and natural logarithm will be positive again. However, the statistical significance of estimator in various models will change. As we can see in the Table 5, the estimator for assets will be statistically significant in respect to Model I in 2009, Model II in 2009 and also during years 2009-2011. This could mean that in order to describe relationship between total indebtedness and size of a business, a variable of total assets appears to be more suitable. Taking into account this fact, the rejection of hypothesis 1 seems questionable.

Table 5 Testing Table

\begin{tabular}{|c|c|c|c|c|c|c|c|c|c|c|}
\hline \multirow{2}{*}{\multicolumn{2}{|c|}{ In assets }} & \multicolumn{4}{|c|}{ Model I } & \multicolumn{4}{|c|}{ Model II } & \multirow{2}{*}{$\begin{array}{c}\text { Model III } \\
09-11 \\
\end{array}$} \\
\hline & & 2009 & 2010 & 2011 & $09-11$ & 2009 & 2010 & 2011 & 09-11 & \\
\hline \multicolumn{2}{|l|}{ estimator } & + & + & + & + & + & + & + & + & + \\
\hline \multicolumn{2}{|c|}{ t-calculated } & 2,4306 & 1,0776 & 0,2815 & 1,2569 & 2,5309 & 1,5503 & 0,9713 & 2,6978 & 0,8999 \\
\hline \multirow{3}{*}{ level of significance } & $\alpha=0,1$ & 1,6895 & 1,6895 & 1,6895 & 1,6582 & 1,6909 & 1,6909 & 1,6009 & 1,6583 & 1,6923 \\
\hline & $\alpha=0,05$ & 2,0301 & 2,0301 & 2,0301 & 1,9808 & 2,0322 & 2,0322 & 2,0322 & 1,9809 & 2,0345 \\
\hline & $\alpha=0,01$ & \begin{tabular}{|l|}
2,7238 \\
\end{tabular} & 2,7238 & 2,7238 & 2,6192 & \begin{tabular}{|l|}
2,7283 \\
\end{tabular} & 2,7283 & 2,7283 & 2,6196 & 2,7332 \\
\hline
\end{tabular}

Source: Own calculations

\section{Hypothesis 2: Tangibility of business affects its capital structure}

The results of comprehensive testing of this hypothesis are summarized in Table 6 . With the exception of the Model I in 2009 , the relationship between total indebtedness and tangibility, expressing collateral value of assets, is negative. This shall mean that the total indebtedness decreases if the value of ratio of long-term tangible assets to total assets of business increases and vice versa.

Table 6 Testing Table

\begin{tabular}{|c|c|c|c|c|c|c|c|c|c|c|}
\hline \multirow{2}{*}{\multicolumn{2}{|c|}{ Tangibility (n T) }} & \multicolumn{4}{|c|}{ Model I } & \multicolumn{4}{|c|}{ Model II } & \multirow{2}{*}{\begin{tabular}{|c|} 
Model III \\
$09-11$ \\
\end{tabular}} \\
\hline & & 2009 & 2010 & 2011 & 09-11 & 2009 & 2010 & 2011 & 09-11 & \\
\hline \multicolumn{2}{|l|}{ estimator } & + & . & . & . & . & . & . & . & . \\
\hline \multicolumn{2}{|l|}{ t-calculated } & 1,6386 & 0,3661 & 2,0872 & 0,1407 & 1,5979 & 0,4210 & 2,1119 & 1,3481 & 4,9988 \\
\hline \multirow{3}{*}{ level of significance } & $\alpha=0,1$ & 1,6895 & 1,6895 & 1,6895 & 1,6582 & 1,6909 & 1,6909 & 1,6909 & 1,6583 & 1,6923 \\
\hline & $\alpha=0,05$ & 2,0301 & 2,0301 & 2,0301 & 1,9808 & 2,0322 & 2,0322 & 2,0322 & 1,9809 & 2,0345 \\
\hline & $\alpha=0,01$ & 2,7238 & 2,7238 & 2,7238 & 2,6192 & 2,7283 & 2,7283 & 2,7283 & 2,6196 & 2,7332 \\
\hline
\end{tabular}

Source: Own calculations

In Table 7, we focus on development of tangibility estimator if the size of business is expressed by natural logarithm of assets.
Table 7 Testing Table

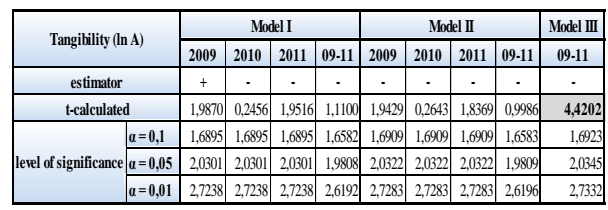

Source: Own calculations

With the exception of the Model III and selected years of Model I and Model II, we rejected the hypothesis of statistical significance of tangibility. This means that:

We reject the hypothesis 2 that tangibility is a statistically relevant variable of the model.

\section{Hypothesis 3: Profitability of business affects its capital structure.}

There is a negative relationship between profitability and total indebtedness of a business. With the exception of Model I and Model II in the year 2011 when the profitability estimator is statistically insignificant, we accepted the hypothesis of statistical significance of a given variable. It is also notable, that this variable is statistically significant even at the level of significance $\alpha=0.1$.

Table 8 Testing Table

\begin{tabular}{|c|c|c|c|c|c|c|c|c|c|c|}
\hline \multirow{2}{*}{\multicolumn{2}{|c|}{ Profitability }} & \multicolumn{4}{|c|}{ Model I } & \multicolumn{4}{|c|}{ Model II } & \multirow{2}{*}{\begin{tabular}{|c|} 
Model III \\
$09-11$ \\
\end{tabular}} \\
\hline & & 2009 & 2010 & 2011 & 09-11 & \begin{tabular}{|l|}
2009 \\
\end{tabular} & \begin{tabular}{|l|}
2010 \\
\end{tabular} & 2011 & \begin{tabular}{|l|}
$09-11$ \\
\end{tabular} & \\
\hline estimator & & - & . & . & . & . & . & . & . & . \\
\hline t-calculate & & 3,5014 & 4,3037 & 1,4436 & 4,3666 & 3,0704 & 3,8626 & 1,4075 & \begin{tabular}{|l|l|l|} 
& 3,9218 \\
\end{tabular} & 2,9703 \\
\hline \multirow{3}{*}{ level of significance } & $a=0,1$ & 1,6895 & \begin{tabular}{|l|l|}
5 & 1,6895 \\
\end{tabular} & 1,6895 & 1,6582 & \begin{tabular}{|l|}
1,6909 \\
\end{tabular} & 1,6909 & 1,6909 & 1,6583 & 1,6923 \\
\hline & e $a=0,05$ & 2,0301 & 2,0301 & 2,0301 & 1,9808 & 2,0322 & 2,0322 & 2,0322 & 1,9809 & 2,0345 \\
\hline & $a=0,01$ & 2,7238 & \begin{tabular}{|l|l|}
8,7238 \\
\end{tabular} & 2,7238 & 2,6192 & \begin{tabular}{|l|}
2,7283 \\
\end{tabular} & 2,7283 & $\begin{array}{l}2,7283 \\
\end{array}$ & \begin{tabular}{|l|l|}
3 & 2,6196 \\
\end{tabular} & 2,73 \\
\hline
\end{tabular}

Source: Own calculations

Table 9 Testing Table

\begin{tabular}{|c|c|c|c|c|c|c|c|c|c|c|}
\hline \multirow{2}{*}{\multicolumn{2}{|c|}{ rofitability }} & \multicolumn{4}{|c|}{ Model I } & \multicolumn{4}{|c|}{ Model II } & \multirow{2}{*}{$\frac{\text { Model III }}{09-11}$} \\
\hline & & 2009 & 2010 & 2011 & 09-11 & 2009 & 2010 & 2011 & 09-11 & \\
\hline estimator & & 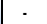 & & . & - & . & - & - & . & - \\
\hline t-calculate & & 4,1626 & 4,5124 & 1,4647 & 4,6834 & 3,4967 & 4,0965 & 1,5867 & 74,2980 & 3,1720 \\
\hline \multirow{3}{*}{ level of significance } & $\alpha=0,1$ & 1,6895 & 1,6895 & 1,6895 & 1,6582 & \begin{tabular}{|l|}
1,6909 \\
\end{tabular} & 1,6909 & 1,6909 & 1,6583 & 1,69 \\
\hline & $\alpha_{\boldsymbol{U}}=\mathbf{0 , 0 5}$ & 2,0301 & 2,0301 & 2,0301 & 1,9808 & 2,0322 & 2,0322 & 2,0322 & \begin{tabular}{|l|l|}
2 & 1,9809 \\
\end{tabular} & 2,03 \\
\hline & $a=0,01$ & 2,7238 & \begin{tabular}{|l|} 
\\
\end{tabular} & 2,7238 & 2,6192 & \begin{tabular}{|l|}
2,7283 \\
\end{tabular} & 2,7283 & 2,7283 & 2,6196 & 2,73 \\
\hline
\end{tabular}

Source: Own calculations

We see (Table 9), that the statistical significance of variable of profitability was also confirmed for this model reflecting the size of a business by natural logarithm of assets. Therefore: 
We accepted hypothesis 3 that profitability is statistically significant variable of the model.

\section{Conclusion}

One of the key areas of financial management of business is deciding on the composition of its resources. Capital structure is essential for successful development of business as it provides for its healthy financial development, overall prosperity and it also decides on its further existence. In other words, the importance of capital structure is determined by its effect on financial risk, profitability and future financial disposition of the business. In addition, suitable adjustment of capital structure is a way to maximize market value of respective business. This means that every business should pay sufficient attention as regards the issues pertaining to capital structure.

\section{Acknowledgement}

The article is an output of the Operational Programme Education, 26110230083: The Quality of Education and Development of Human Resources as pillars of the knowledge society, The Faculty of Operation and Economics of Transport and Communications, University of Žilina, Slovak Republic.

\section{References}

[1] Bauer, P.: Determinants of Capital Structure: Empirical Evidence from the Czech Republic. Czech Journal of Economics and Finance, 54, pp. 2-21. 2004.

[2] Brigham, E. F. - Houston J. F.: Fundamentals of Financial Management, South-western College Publisher 2006, ISBN 0-32431-980-0.

[3] Booth, L - Aivazian, V. - DemirgucKunt, A, Maksimovic, V.: Capital
Structure in Developing Countries. Journal of Finance, 56, PP. 87-130. 2001.

[4] Durand, D.: Cost of Debt and Equity Funds for business. New York, National Bureau of Economic Research, 1952, ISBN 12-3264-187-9.

[5] Fama, E.F. - French, K.R.: Testing Trade-off and Pecking Order Predictions about Dividends and Debt. Review of Financial Studies, 15, pp.1-33. 2002.

[6] Frank, M. Z. - Goyal, V. K.: Testing the Pecking Order Theory of Capital Structure. Journal of Financial Economics. 67, pp. 217-248. 2003.

[7] Jensen, M.C.: Agency Costs of Free Cash-flow, Corporate Finance, and Takeovers. American Economic Review. 76, pp. 323-329. 1986.

[8] MacKinnon, J. - White, H. - Davidson, R.: Tests for Model Specification in the Presence of Alternative Hypotheses: Some Further Results. Journal of Econometrics, 21, pp. 53-70. 1983.

[9] Schumpeter, J.A: The Theory of Economic Development: An Inquiry into Profits, Capital, Credit, Interest, and the Business Cycle, Transaction Publishers, 1982, ISBN 978-087-8556984

[10] Shyam-Sunder, L. - Myers, S.: Testing Static Trade-off against Pecking Order Models of Capital Structure. Journal of Financial Economics, 51, pp. 219-244. 1999.

[11] Smith, W.S. Jr.: Agency Costs. In Eatwell, J., Milgate, M., Newman, P., Finance. London: Macmillan Press, Ltd. 1989.

[12] Swanson, Z. - Srinidhi B. Seetharaman, A.: The capital structure paradigm: evolution of debt/equity choices, Preager Publisher, 2003, 245 s., s 130, ISBN 1-56720-616-6

[13]Titman, S. - Wessels, R.: The Determinants of Capital Structure Choice. Journal of Finance, 43, pp. 1-19. 1988. 